\title{
Polish version of the Intermittent Claudication Questionnaire
}

\author{
Ewelina Rosloniec', Anita Kulik², Alun H. Davies ${ }^{3}$, Piotr Mika' \\ 'Department of Clinical Rehabilitation, University of Physical Education in Krakow, Poland \\ ${ }^{2}$ Department of Rehabilitation, University School of Physical Education in Poznan, Faculty of Physical Education \\ in Gorzow Wielkopolski, Poland \\ ${ }^{3}$ Department of Surgery \& Cancer, Faculty of Medicine, Imperial College of Medicine, Charing Cross Hospital, London, England
}

\begin{abstract}
Introduction. The assessment of health-related quality of life includes the assessment of physical condition and motor skills, mental condition, social and economic situation, and somatic experiences. The specific questionnaires used in patients with intermittent claudication include i.a. Peripheral Artery Questionnaire, Vascular Quality of Life Questionnaire, PAD Quality of Life Questionnaire, and Walking Impairment Questionnaire, which is the only one of the aforementioned questionnaires that is available in Polish. The Intermittent Claudication Questionnaire (ICQ) available in English is a specific instrument for assessing the quality of life of patients with intermittent claudication. This paper attempts at evaluating the reliability of the Polish version of ICQ.
\end{abstract}

Material and methods. The process of validation of the Polish version of the questionnaire involved translating the questionnaire and evaluating the newly translated tool in order to compare the results on international level for the possibility of its practical use for assessment of health-related quality of life in patients with intermittent claudication in Poland. In order to evaluate the reliability and coherence of the questionnaire, the methods of internal consistency in Cronbach's $\alpha$, as well as the intraclass correlation coefficient were applied for specific questions and for the final result of the questionnaire.

Results. The Cronbach's $\alpha$ as the questionnaire's reliability index was 0.915 . Intraclass correlation calculated for the total score of the questionnaire's answers was 0.97.

Conclusions. The Polish version of the Intermittent Claudication Questionnaire is a repeatable and reliable research tool for assessing the health-related quality of life in patients with intermittent claudication.

Key words: intermittent claudication, atherosclerosis, quality of life, repeatability

Acta Angiol 2016; 22: 4: 150-157

\section{Introduction}

In medicine, the term quality of life is used to refer to the so called health-related quality of life (HRQoL), which can be described as the functional effect of a disease and a treatment for the patient $[1,2]$. The assessment of health-related quality of life includes the assessment of physical condition and motor skills, mental condition, social and economic situation, and somatic experiences. The questionnaires used for assessing the quality of life can be divided into general questionnaires enabling the assessment of a wide population of both patients suffering from diseases and healthy people, questionnaires specific to a given disease or group of diseases, and mixed questionnaires for assessing the quality of life in a specific ailment, but also including general elements [I]. The specific questionnaires used in patients with intermittent claudication include i.a. Peripheral Artery Questionnaire (PAQ) [3], Vascular Quality of Life Questionnaire (VascuQoL) [4], 
PAD Quality of Life Questionnaire (PADQoL) [5] and Walking Impairment Questionnaire (WIQ) [6, 7]. PAQ comprises of 20 elements, and it assesses the degree of motor skills, symptoms and their stability, patient's satisfaction with the course of treatment, the quality of life and social activity. VascuQoL assesses 5 domains of health in patients with ischaemia of lower extremities, however, in the opinion of some researches, it has no wider applications [I]. PADQoL comprising of 38 questions is used to assess the influence of ischaemia of lower extremities on physical condition, mental-social status and emotional condition of patients [5]. The aforementioned WIQ comprises of $2 \mathrm{I}$ questions. It is used for the assessment of distance to claudication, walking pace, intensity of claudication and the ability to climb stairs, however, apart from physical condition, ailments and motor skills, it does not fully assess all domains of HRQoL [6]. As the assessment of mental condition of patients and their social-economical situation is omitted, WIQ should be considered a specific tool only for the assessment of functional capabilities. Apart from WIQ, none of the aforementioned tools is available in Polish language version [8].

In response to the need for a Polish version of a specific health-related quality of life questionnaire for patients with intermittent claudication, this paper describes the attempt to adapt the Intermittent Claudication Questionnaire and to evaluate the reliability of the Polish version of this questionnaire.

\section{Structure of the Questionnaire}

The Intermittent Claudication Questionnaire (ICQ) was developed and validated by a research team headed by Alun $\mathrm{H}$. Davies from the Imperial College School Of Medicine, Charing Cross Hospital [9, I0]. Based on the medical histories of 24 patients with intermittent claudication, the main problems influencing the quality of life, resulting from intermittent claudication, were identified. After consulting a team of 4 experts from the field of vascular diseases ( 2 vascular surgeons and 2 vascular nurses), a pilot version of the questionnaire was drawn up, comprising of 18 questions. The group taking part in the pilot study included 124 subjects with intermittent claudication. The final version of the questionnaire comprised of 16 questions. The value of Cronbach's $\alpha$ was estimated for the final, 16-part version of the questionnaire. The intraclass correlation (test - retest) of the questionnaire was evaluated after 14 days from the first study in a group of 58 subjects, who did not report any changes in the intensity of symptoms within 2 weeks from the first study. The value of Cronbach's $\alpha$ was estimated at 0.94 , the intraclass correlation at 0.95 .
The English version of the Intermittent Claudication Questionnaire, also called Charing Cross Symptom Specific Claudication Questionnaire (CCCQ), is a specific instrument for the assessment of the quality of life of patients with intermittent claudication (Appendix No. I) $[9,10]$. The Intermittent Claudication Questionnaire comprises of 16 questions. Patients evaluate the degree of influence intermittent claudication has on their life.

\section{Answer key}

The maximum number of points to score with answers to the questions is 80 . In order to arrive at the final result of the questionnaire, the total number of points scored in all the questions should be presented in a scale from 0 to 100 , where 0 is the best possible score (the best possible quality of life/the best health condition), and 100 is the worst possible score (the worst possible quality of life/the worst possible result of examination of health condition). E.g. if the total number of points from the questions is 40 points, the final score will be $50(40 / 80 * 100=50)$. The higher the score, the lower the quality of life. The improvement of health-related quality of life is reflected by a reduction of the questionnaire score. Numbers of points scored for individual questions are provided in the Appendix No. 3.

\section{Material and methods}

The process of validation of the Polish version of the questionnaire comprised of two stages: translating the questionnaire and evaluating the newly translated tool in order to compare the results on international (intercultural) level for the possibility of its practical use for assessment of health-related quality of life in patients with intermittent claudication in Poland [1 I, 12]. After contacting the questionnaire's author, he agreed for it to be used, translated and validated. A Polish version of the questionnaire was prepared, maintaining equivalence with the original. The translation was performed by a sworn translator of the English language, English philology graduate, native speaker of Polish. The questionnaire's translation was verified by a specialist in the field of vascular diseases. Based on the analysis of the available literature, it was evaluated that the term "health-related quality of life" has the same definitions in Poland and in the United Kingdom. Afterwards, based on the translations, the questionnaire was prepared, consistent with the original (Appendix No. 2) as far as the graphic layout, the number and form of questions, and the instructions are concerned.

157 subjects took part in the study $(47+, 110$ ð), aged $67 \pm 8$, diagnosed with IIA and IIB Fontaine stages of atherosclerosis obliterans of arteries in lower extremities, stable symptoms of intermittent claudica- 
Table I. Intraclass Correlation Coefficient (ICC) for specific questions and for the total score of the questionnaire

\begin{tabular}{|l|l|c|}
\hline Question & & ICC \\
\hline I. & Intensification of pain & 0.86 \\
\hline 2. & Crossing the road & 0.85 \\
\hline 3. & Using the bus, train or tube & 0.88 \\
\hline 4. & Climbing several flights of stairs & 0.88 \\
\hline 5. & Climbing one flight of stairs & 0.9 \\
\hline 6. & Walking more than a mile & 0.84 \\
\hline 7. & Walking I00 yards & 0.9 \\
\hline 8. & Going out of the house & 0.85 \\
\hline 9. & Number of rests caused by leg pains & 0.85 \\
\hline I0. & Time spent thinking about leg pains & 0.86 \\
\hline II. & Time spent feeling downhearted and low because of leg pains & 0.87 \\
\hline I2. & Worrying that leg pains would get worse & 0.85 \\
\hline I3. & Interference with normal work & 0.89 \\
\hline I4. & Interference with hobbies or pastimes & 0.86 \\
\hline I5. & Interference with social activities & 0.87 \\
\hline 16. & Interference with doing errands (shopping, going to the post office or bank, etc.) & 0.89 \\
\hline TOTAL & & 0.97 \\
\hline
\end{tabular}

tion and ankle-brachial index of not more than 0.9 . The subjects were recruited in the Centre for Cardiac and Vascular Diseases. The manner of selecting subjects for the study group was the same as the one used in validation of the original version of the questionnaire. The intermittent claudication questionnaire was used twice - the second study was conducted one week later. Both studies were conducted by the same investigator. In order to evaluate the reliability and coherence of the questionnaire, the methods of internal consistency in Cronbach's $\alpha$, as well as the Intraclass Correlation Coefficient (ICC) were applied for specific questions and for the final result of the questionnaire. The exclusion of specific questions from the analysis was simulated in order to check for potential improvement of coherence and reliability expressed by Cronbach's $\alpha$. The statistical analysis was conducted by means of Statistica. I 0 software. The results were considered significant with $p<0.05$.

\section{Results}

The results of Intraclass Correlation Coefficient (ICC) calculated for specific questions and for the total number of points scored in the questionnaire are presented in the table (Tab. I).

The greatest repeatability of answers was observed in questions concerning limitations in climbing one flight of stairs and walking 100 yards (questions 5 and 7). The lowest ICC value was estimated for question 6 concerning limitation in walking I mile. The ICC value
Table 2. The coherence of the questionnaire after excluding specific questions

\begin{tabular}{|l|c|}
\hline $\begin{array}{l}\text { Question excluded from } \\
\text { the analysis }\end{array}$ & $\begin{array}{c}\text { Anticipated value } \\
\text { of Cronbach's } \alpha\end{array}$ \\
\hline I. & 0.912 \\
\hline 2. & 0.911 \\
\hline 3. & 0.909 \\
\hline 4. & 0.908 \\
\hline 5. & 0.910 \\
\hline 6. & 0.912 \\
\hline 7. & 0.908 \\
\hline 8. & 0.909 \\
\hline 9. & 0.914 \\
\hline 10. & 0.912 \\
\hline 11. & 0.908 \\
\hline 12. & 0.908 \\
\hline 13. & 0.907 \\
\hline 14. & 0.910 \\
\hline 15. & 0.908 \\
\hline 16. & 0.905 \\
\hline
\end{tabular}

for specific questions was not lower than 0.84 . The ICC value for the whole questionnaire was 0.97 .

The Cronbach's $\alpha$ used as the questionnaire's reliability index was 0.915 .

Table 2 presents the anticipated Cronbach's $\alpha$ for the whole questionnaire estimated after excluding specific questions. None of the recorded values of 
Cronbach's $\alpha$ was higher than 0.915, which was estimated for the whole questionnaire in initial version. Exclusion of any question from the questionnaire would not improve its coherence.

\section{Discussion}

The most frequently used research tool in studies searching for an effective form of physical training for patients with intermittent claudication is the assessment of covered walking distance [7, 9, 13-15]. Usually, the authors use a graded treadmill walking test according to Gardner protocol, identifying time to claudication and the maximum walking time [7, 15]. Despite showing that this test is characterised by a repeatability of results and its good acceptability by the subjects, there are some reservations. First of all, the test results can be influenced by the so called learning effect - this concerns the studies with the form of training being treadmill walking [16]. Additionally, for some patients the continuation of exertion until maximum pain is impossible due to limitations caused by concomitant disease of circulatory/respiratory system [17]. The reservations are also related to the view that the treadmill result of a patient does not correlate with his/her subjective assessment of disability [18].

The last remark is also related to the degree of improvement of the covered walking distance achieved after completion of the training programme, which (according to patients) does not correspond to the degree of improvement of walking outside. Therefore, the assessment of a patient with intermittent claudication should include evaluation of the quality of life, i.a. how such a patient deals with daily activities at work, at home and outside [13]. The studies of the quality of life of patients with intermittent claudication employed various general questionnaires, i.e. Short Form-36 [19, 20], Nottingham Health Profile [2I] or EuroQol [22]. As rightly pointed out by Chong et al. [9], the non-specific character of these tools can skip certain aspects of the quality of life closely related to intermittent claudication, leading, in her opinion, to missing significant changes. The evaluation of the health-related quality of life is a significant element of a clinical study, as treatment should be selected in accordance with specific symptoms and issues, the patients with ischaemia of lower extremities have to deal with. A wider perspective, going beyond physical limitations, such as shortened walking distance or difficulties in climbing stairs, should be especially important in order to see if the disease is not making social life difficult or if it is not a source of anxiety. The ICQ meets these criteria.

The results recorded by the authors of the questionnaire expressly show that it is a reliable research tool [9]. The Cronbach's $\alpha$ estimated in validation of the original version was 0.94 . This value is understood that approximately $94 \%$ of variability of the total result was variability of the true result, which proves a very high reliability of the scale [23]. In our own studies, we recorded the value close to the result of the original version, namely 0.915 , which enables us to conclude that the reliability of the Polish version of the questionnaire is not different from the original version. In reference to the results presented in Table 2, it should be pointed out that regardless which question is excluded from the final version of the questionnaire, the anticipated values of Cronbach's $\alpha$ will be from 0.905 to 0.914 . These values are lower than 0.915 , which means that modification of the 16-question version is not necessary.

The intraclass correlation calculated by the authors of the original version was 0.95 , and in our studies it was 0.97 for the total score from answers to the questionnaire. The ICC results close to I mean high consistency (high repeatability) in the evaluation of specific issues, in this case the answers provided by patients to the same question after a given interval. The results close to - I show lack of consistency in the evaluation of specific issues [23]. Hallgren evaluates the intraclass correlation as good at the level of 0.60-0.74 and excellent at the level of 0.75-1.0 [24]. The above results show coherence of structure of the Polish version of the ICQ, comparable to the coherence of the original version. In literature, we can also find the German version of ICQ developed by Kirchberger et al [25]. Although the preliminary studies to check the time of filling out the questionnaire and understand questions were conducted in a group of $8 \mathrm{I}$ subjects, the secondary study to evaluate the reliability and coherence of the questionnaire was conducted after 2 weeks in a group of only 13 subjects. The Cronbach's $\alpha$ of the German version was estimated at 0.75 , and the intraclass correlation at $r=0.88$. Ketenci et al. [26] engaged in validation of the Turkish version of ICQ. Out of 83 subjects participating in the first study, 30 filled out the questionnaire after one day. The Cronbach's $\alpha$ was estimated at 0.95 , and the intraclass correlation at $r=$ 0.91 . Although the results of validation of the Turkish version seem similar to the results of validation of the Polish version, the short interval between subsequent studies raises certain doubts. In our opinion, the interval between the studies should be longer to make sure that the patients do not remember the answers provided in the first study.

Regardless of the reliability of the questionnaire, the practicality of using a tool should also be considered. Too many questions can discourage patients to provide answers or cause them to lose focus and provide answers in a hurry, which not necessarily will be truthful. 
Also, the time of filling out the questionnaire is very important. In our own studies this time was not measured, but the authors of the original version reported it to be on average 3.7 minutes, and on average 6.3 minutes in the German version $[9,25]$. Regardless of the language version, the ICQ was widely accepted by patients and considered easy to fill out. To sum up, the attained results enable us to recommend the Polish version of the questionnaire as a reliable research tool for the evaluation of healthrelated quality of life in patients with intermittent claudication.

The availability of specific tools allows us to perform more detailed evaluations of the influence of ischaemia of lower extremities on the functioning of patients with intermittent claudication. However, the lack of specific tools for evaluation of other aspects of HRQoL in patients with atherosclerosis, such as self-perception, satisfaction from life, mental burden or emotional well-being, should be a stimulus for their further development.

\section{Conclusions}

The Polish version of the Intermittent Claudication Questionnaire is a repeatable and reliable research tool for assessing the health-related quality of life in patients with intermittent claudication. The Intermittent Claudication Questionnaire is a recommended research tool for both daily clinical practice and for scientific research.

\section{References}

I. Piotrkowska R, Dobosz M, Książek J et al (20II) Jakość życia chorych z miażdżycą naczyń obwodowych — przegląd piśmiennictwa. Ann Acad Med Gedan; 41: 89-95.

2. Cieślik B, Podbielska B (2015) Przegląd wybranych kwestionariuszy oceny jakości życia. Inż Biomed; 21: 102-135.

3. Spertus J, Jones P, Poler S (2004) The peripheral artery questionnaire: $A$ new disease-specific health status measure for patients with peripheral arterial disease. Am Heart; 147: 30I-308.

4. Morgan MBF, Crayford T, Murrin B et al (200I) Developing the Vascular Quality of Life Questionnaire: A new disease-specific quality of life measure for use in lower limb ischemia. J Vasc Surg; 33: 679-687.

5. Treat-Jacobson D, Lindquist RA, Witt DR et al (2012) The PADQOL: Development and validation of a PAD-specific quality of life questionnaire. Vasc Med; 17: 405-4I5.

6. Regensteiner J, Steiner JF, Panzer RJ et al (1990) Evaluation of walking impairment by questionnaire in patients with peripheral arterial disease. J Vasc Med Biol; 2: 142-152.

7. Mika P, Andrzejczak A, Konik A et al (20I I) Kliniczne metody oceny pacjentów z chromaniem przestankowym. Reh Med; 15: 10-20.
8. Spodaryk K, Mika P, Dróżdż W et al (1999) Czynnościowa ocena leczenia chorych z chromaniem przestankowym. Med Sport; 3: 191-199.

9. Chong P, Garratt A, Golledge J et al (2002) The Intermittent Claudication Questionnaire: a patient-assessed condition-specific health outcome measure. J Vasc Surg; 36: 764-77I.

10. Cheetham D, Burgees L, Ellis M et al (2004) Does supervised exercise offer adjuvant benefit over exercise advice alone for the treatment of intermittent claudication? A randomised trial. Eur J Endovasc Surg; 27: 17-23.

II. Jaracz K (200I) Adaptacja kulturowa narzędzi badawczych do oceny jakości życia. [In]: Wołowicka $L$ (ed) Jakość życia w naukach medycznych; 28I-290.

12. Gawlik M, Kurpas D (1995) Zasady walidacji kwestionariuszy na przykładzie kwestionariusza Caregiver Quality Of Life-Cancer. Puls Uczelni; 8: 26-29.

13. Hiatt WR, Hirsh AT, Regensteiner JG (1995) Clinical trials for claudication. Assessment of exercise performance, functional status, and clinical end points. Circulation; 92: 614-62I.

14. Brzostek T, Mika P, Bromboszcz J (2004) Miażdżyca tętnic kończyn dolnych - patofizjologia, klinika, leczenie i rehabilitacja. Reh Med; 8: 38-50.

15. Gardner AW, Poehlman ET (1995) Exercise rehabilitation programs for the treatment of claudication pain: a meta-analysis. JAMA; 274: 975-980.

16. Dean E, Ross J, Bartz J (1989) Improving the validity of clinical exercise testing: the relationship between practice and performance. Arch Phys Med Rehabil; 70: 599-604.

17. Chong PFS, Davies AH, Greenhalgh RM (2000) The suitability of treadmill based exercise training for intermittent claudication. Br J Surg; 87: 22.

18. Barletta G, Perna S, Sabba C (1996) Quality of life in patients with intermittent claudication: relationship with laboratory exercise performance. Vasc Med; I: 3-7.

19. Chetter IC, Spark JI, Dolan P et al (1997) Quality of life analysis in patients with lower limb ischaemia: suggestions for European standardisation. Eur J Vasc Endovasc Surg; 13: 597-604.

20. Currie IC, Wilson YG, Baird RN et al (1995) Treatment of intermittent claudication: the impact on quality of life. Eur J Vasc Endovasc Surg; 10: 356-361.

21. Tisi P, Shearman C (1999) The impact of treatment of intermittent claudication on subjective health of the patient. Health Trends; 30: 109-114.

22. Chetter IC, Dolan P, Spark JI et al (1997) Correlating clinical indicators of lower-limb ischaemia with quality of life. Cardiovasc Surg; 5: 361-366.

23. Stanisz A (2007) Przystępny kurs statystyki z zastosowaniem STATISTICA.PL na przykładach z medycyny. Tom 3. Analizy wielowymiarowe. StatSoft Polska Sp. z o.o. Kraków.

24. Hallgren KA (20/2) Computing Inter-Rating Reliability for Observational Data Tutor Quant Psychol; 8: 23-34.

25. Kirchberger I, Finger T, Muller-Buhl U (2013) A German version of the Intermittent Claudication Questionnaire (ICQ): cultural adaptation and validation. Vasa; 4I: 333-342.

26. Ketenci B, Tuygun AK, Gorur A et al (2009) An approach to cultural adaptation and validation: the Intermittent Claudication Questionnaire. Vasc Med; 14: I17-122. 


\section{Appendix No. I. The Intermittent Claudication Questionnaire — the original version}

Appendix, online only. ICQ.

Appendix A: The intermittent Claudication Questionnaire (ICO)

Pains, Cramps, Numbness or Dlscomfort in Your Calvas, Thighs or Buttocks

The questions below ask about the problems of pains, cramps, and numbness or discorffort that patients with arterial disease get in their calves, thighs or buttocks when walking The term "leg pains" has been used to describe all of these problems. Please answer every question with a tick. If you are unsure about how to answer a question, please give the
best answer you can. When answering each question think about any pains, cramps, numbness or discorffort that you may get in your calves, thighs or buttocks when welking. Thiek only one box per question.

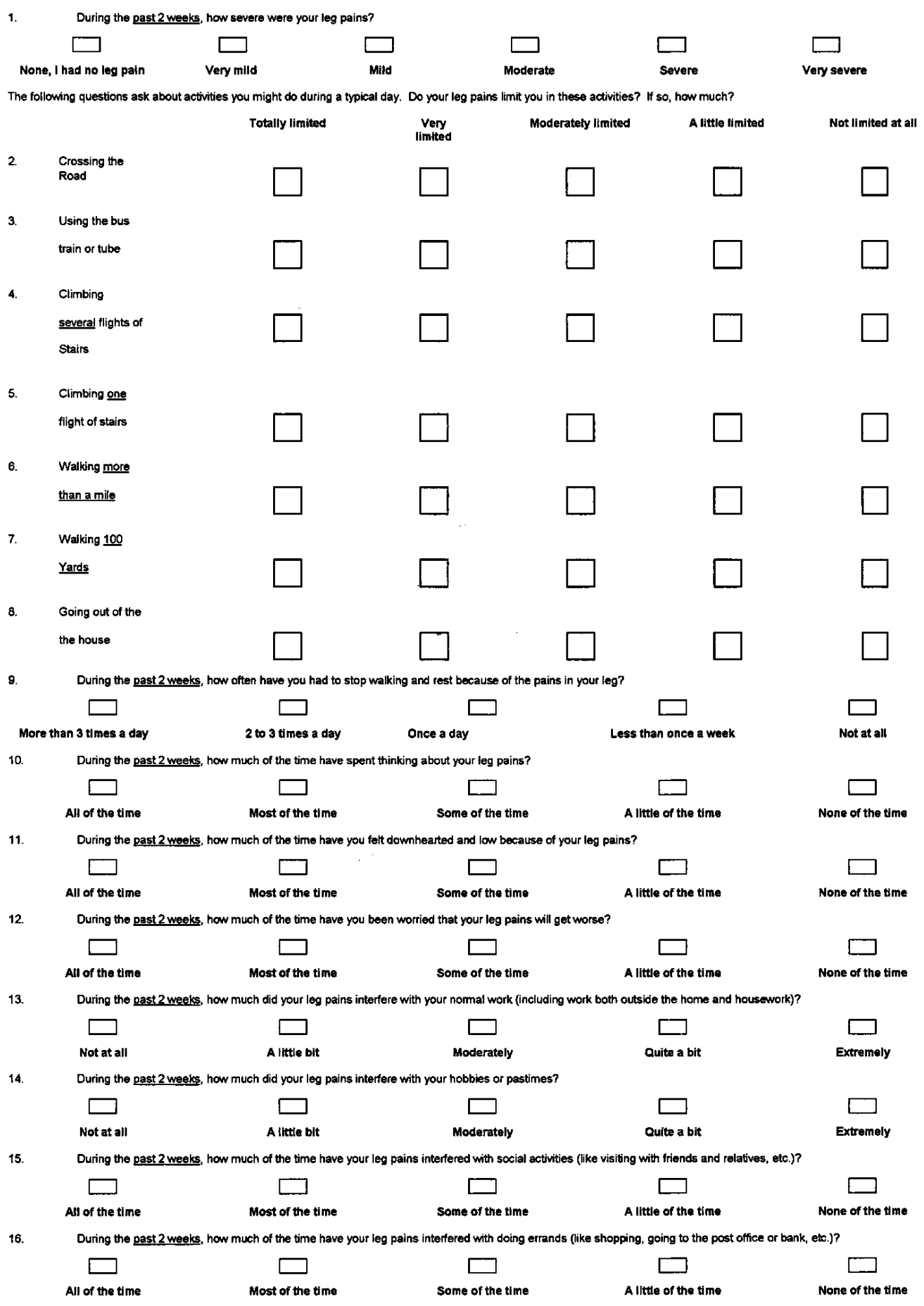




\title{
Appendix No. 2. The Intermittent Claudication Questionnaire - Polish version
}

\begin{abstract}
KWESTIONARIUSZ CHROMANIA PRZESTANKOWEGO ALUN H. DAVIES
THE INTERMITTENT CLAUDICATION QULST
CLUDICATION OUESTIONNAIRE (CCCO)

Poniższe pytania dotyczą dolegliwości bolowych, drętwienia, dyskomfortu, skurczów mięsniowych, ktt́re chorzy z miażdżycą tettnic Ponizsze pytania dotycza dolegliwosci bolowych, dretwienia, dyshomfor

wszystkich tych dolegliwošci. Proszz̨ odpowiedzieć na wszystkie pytania zaznaczając tylko jedną wiasciwą odpowiedź. Jesti są

wątpliwości, którą odpowiedz wybrać należy zaznaczyé najbliższą prawdzie. Odpowiadając na pytania nalę̇y wziąć pod uwag

wszystkie dolegliwosci bólowe, skurcze, drętwienia lub dyskomfort pojawiający się w łydkach, udach lub posłladkach podeza
\end{abstract}

1. Jak silne dolegliwości bólowe nóg miałeś $\mathrm{w}$ czasie ostatnich 2 tygodni?

$\begin{array}{cccccc}\square & \square & \square & \square & \square & \square \\ \text { NIE MIALEM } & \text { BARDZOMALE } & \text { MALE } & \text { UMIARKOWANE } & \text { SILNE } & \text { BARDZO SLNE }\end{array}$

Kolejne pytania dotycza czynności które mogteś ostatnio wykonywać. Czy ból nóg ogranicza cię w tych czynnościach? JAK BARDZO?

$\begin{array}{lllll}\text { CALKOWICIE } & \text { BARDZO } & \text { UMIARKOWANIE } & \text { NIEWIELE } & \text { WCALE NIE } \\ \text { OGRANICZA } & \text { OGRANICZA } & \text { OGRANICZA } & \text { OGRANICZA } & \text { OGRANICZA }\end{array}$

$\begin{array}{llllll}\begin{array}{l}\text { 2. Przechodzenie przez } \\ \text { ulicę }\end{array} & \square & \square & \square & \square & \square \\ \begin{array}{l}\text { 3. Korzystanie z autobusu, } \\ \text { tramwaju, pociagu }\end{array} & \square & \square & \square & \square & \square \\ \begin{array}{l}\text { 4. Wchodzenie kilku } \\ \text { pięter po schodach }\end{array} & \square & \square & \square & \square & \square \\ \begin{array}{l}\text { 5. Wchodzenie jednego } \\ \text { piętra po schodach }\end{array} & \square & \square & \square & \square & \square \\ \text { 6. Marsz powyżej 1500 m } & \square & \square & \square & \square & \square \\ \text { 7. Przejście 100 m } & \square & \square & \square & \square & \square \\ \text { 8. Wychodzenie z domu } & \square & \square & \square & \square & \square\end{array}$

9. W czasie ostatnich 2 tygodni jak często musiałeś się zatrzymywać i odpoczywać z powodu bólu w nogach?

$\begin{array}{ccccc}\square & \square & \square & \square & \square \\ \text { 3 RAZCEI NZIEN } & \begin{array}{c}\text { 2 DO 3 RAZY } \\ \text { DZIENNIE }\end{array} & \text { 1 RAZ DZIENNE } & \begin{array}{c}\text { MNIEJ Nİ RAZ } \\ \text { NA TYDZIEN }\end{array} & \text { WCALE }\end{array}$

10. W czasie ostatnich 2 tygodni jak często myślałes o dolegliwościach bólowych nóg?

$$
\begin{array}{ccccc}
\square & \square & \square & \square & \square \\
\text { CAIY CZAS } & \text { BARDZO CZESSTO } & \text { CZASAMI } & \text { RZADKO } & \square \text { WCALE }
\end{array}
$$

11. W czasie ostatnich 2 tygodni jak często czułeś siẹ przybity i przygnębiony z powodu bólu nóg?

$$
\begin{array}{ccccc}
\square & \square & \square & \square & \square \\
\text { CAEY CZAS } & \text { BARDZO CZESTO } & \text { CZASAMI } & \square
\end{array}
$$

12. W czasie ostatnich 2 tygodni jak często martwiłeś się, ze dolegliwości bólowe w nogach mogą się nasilié?

$$
\begin{array}{ccccc}
\square & \square & \square & \square & \square \\
\text { CAEY CZAS } & \square & \square \\
\text { BARDZO CZESTO } & \text { CZASAMI } & \text { RZADKO } & \text { WCALE }
\end{array}
$$

13. W czasie ostatnich 2 tygodni jak bardzo ból w nogach ograniczał twoją normalną pracę ( $w$ domu i poza domem)?

$$
\begin{array}{lcccc}
\square & \square & \square & \square & \square \\
\text { WCALE } & \square & \square \\
\text { NIEWIELE } & \text { UMMACZNIE } & \text { OGROMNIE }
\end{array}
$$

14. W czasie ostatnich 2 tygođni jak bardzo ból w nogach ograniczał twoją aktywnośc w czasie wolnym (wypoczynek, hobby)?

$$
\begin{array}{lcccc}
\square & \square & \square & \square & \square \\
\text { WCALE } & \square \text { NIEWIELE } & \square \text { UMARKOWANE } & \square \text { ZNACZNIE } & \square \text { OGROMNIE }
\end{array}
$$

15. W czasie ostatnich 2 tygodni jak często ból w nogach ograniczał twoje kontakty ze znajomymi, krewnymi oraz inną aktywność społeczną?

$$
\begin{array}{ccccc}
\square & \square & \square & \square & \square \\
\text { CALY CZAS } & \text { BARDZO CZESTO } & \square \text { CZASAMI } & \text { RZADKO } & \square \text { WCALE }
\end{array}
$$

16. W czasie ostatnich 2 tygodni jak często ból w nogach ograniczał cię w załatwianiu różnych spraw (zakupy, wyjście na pocztę, do banku itp )

$$
\begin{array}{ccccc}
\square & \square & \square & \square & \square \\
\text { CAEY CZAS } & \text { BARDZO CZESTO } & \square \text { CZASAMI } & \square \text { RZADKO }
\end{array}
$$


Appendix No. 3. The Intermittent Claudication Questionnaire — the score

\section{Answers for the question I}

None, I had no leg pain -0 pts

Very mild - I pts

Mild - 2 pts

Moderate -3 pts

Severe -4 pts

Very severe -5 pts

\section{Answers for questions 2-8}

Totally limited -5 pts

Very limited -3.75 pts

Moderately limited - 2.5 pts

A little limited - I.25 pts

Not limited at all -0 pts

\section{Answers for the question 9}

More than 3 times a day -5 pts

$2-3$ times a day -3.75 pts

Once a day - 2.5 pts

Less than once a week -1.25 pts

Not at all -0 pts

\section{Answers for questions 10-16}

All the time/Extremely - 5 pts

Most of the time/Quite a bit -3.75 pts

Some of the time/Moderately -2.5 pts

A little of the time/A little bit - 1.25 pts

None of the time/Not at all -0 pts 